DOI: $10.17707 /$ AgricultForest.64.4.15

\author{
Sabrija ČADRO*, Otilija MISECKAITE, \\ Teofil GAVRIĆ, Raimundas BAUBLYS and Jasminka ŽUROVEC ${ }^{1}$
}

\title{
IMPACT OF CLIMATE CHANGE ON THE ANNUAL WATER BALANCE IN A HUMID CLIMATE
}

\begin{abstract}
SUMMARY
Lithuania and Bosnia and Herzegovina are considered as countries with high vulnerability and low adaptive capacity to cope with climate change. The entire territory of these countries is characterized by the warming trend, with positive trends in both the maximum and the minimum temperatures throughout the year. The increase in air temperature has resulted in change of evapotranspiration and mean annual water balance values. These countries are also frequently faced with an occurrence of severe droughts and heavy floods. The main purpose of this study was to determine and compare the severity of changes in mean annual water balance for two humid climatic zones, in order to understand how different areas of similar climate characteristics react to climate change and to analyze the significance of their influence. Monthly weather data from two weather stations, Kaunas (Lithuania) and Sarajevo (Bosnia and Herzegovina), for the time period of 30 years $(1988$ - 2017) were used to determine and analyze the mean annual water balance. The results indicate that climate change has a different effect on the water balance of these two humid areas. Both locations showed a positive trend of reference evapotranspiration, with an increase of $1.450 \mathrm{~mm}$ year $^{-1}$ to $1.503 \mathrm{~mm}_{\text {year }}{ }^{-1}$. However, the total runoff and soil moisture deficit are decreasing in Kaunas (-0.480 mm and -2.114 $\mathrm{mm}_{\text {year }}{ }^{-1}$, respectively), while they are increasing in Sarajevo (0.492 $\mathrm{mm}$ and $0.485 \mathrm{~mm}$ year $^{-1}$, respectively).
\end{abstract}

Keywords: climate change, water balance, humid climate, Bosnia and Herzegovina, Lithuania

\section{INTRODUCTION}

Human pressure on the natural environment resulted in the decrease in availability of freshwater supplies for consumption and agricultural production. Global climate change and associated impacts on water resources are the most urgent challenges facing mankind today and will have enduring societal implications for generations to come. Potential impacts may include the changes

\footnotetext{
${ }^{1}$ Sabrija Čadro (corresponding author: s.cadro@ppf.unsa.ba), Teofil Gavrić and Jasminka Žurovec, Faculty of Agriculture and Food Sciences, University of Sarajevo, BOSNIA AND HERZEGOVINA; Otilija Miseckaite, Raimundas Baublys, Aleksandras Stulginskis University, Kaunas, LITHUANIA

Paper is presented on Green Room Sessions - International Conference, Podgorica 2018

Notes: The authors declare that they have no conflicts of interest. Authorship Form signed online.
} 
in watershed hydrologic processes including timing and magnitude of surface runoff, stream discharge, evapotranspiration, drought occurrence and flood events (Simonovic \& Li, 2004). There is an essential need for effective management of limited water resources while increasing agricultural productivity (Sharma \& Irmak, 2012).

Lithuania and Bosnia and Herzegovina (B\&H) are considered as countries with high vulnerability and low adaptive capacity to cope with climate change (Easterling et al., 2000; Žurovec et al., 2017). The entire territory of these countries is characterized by the warming trend with positive trends in both the maximum and the minimum temperatures throughout the year (Radusin et al., 2013; Radusin et al., 2016; Merl, 2017; Popov et al., 2018; Povilaitis et al., 2018).

The average annual precipitation from 1977 to 2016 was $642 \mathrm{~mm}$, or 1.4\% higher than the climate normal (CN, defined as the three-decade 1981-2010 average) in Kaunas, Lithuania. The annual air temperatures in Kaunas for the 1977-2016 period (with an average of $7.0^{\circ} \mathrm{C}$ ) showed increasingly variable patterns (Povilaitis et al., 2018). According to Trbic et al. (2017) the entire territory of $\mathrm{B} \& \mathrm{H}$ is characterized by prominent and significant annual warming. The annual temperature increase was in the range of $0.2-0.5^{\circ} \mathrm{C}$ per decade (Radusin et al., 2016; Trbic et al., 2017). In addition, increase in the extreme precipitation is present over the entire territory of Bosnia and Herzegovina (Popov et al., 2017).

The increase in air temperature and changes in precipitation amount has resulted in change of evapotranspiration $\left(E T_{0}\right)$ and mean annual water balance values (Giugliano et al., 2013). Water balance is important for determination of water availability, crop irrigation requirement, flood risk assessment, regional water management decision-making, drought analyses, environmental studies, understanding the possibilities of organizing agricultural production in a given area and it is used to model climate change impacts and design effective adaptation and mitigation measures (Žurovec, 2012; Pereira et al., 2015; Pandey et al., 2016; Čadro S. et al., 2017; Žurovec et al., 2017).

Thornthwaite and Mather (1955) developed a simple heuristic model of water balance that estimates monthly actual evapotranspiration (AET), runoff $(R O)$ and soil moisture deficit $(S M D)$ as a function of soil-moisture storage and potential evapotranspiration (PET) via a "bookkeeping" procedure. Since then, many authors developed a large number of different versions of this water balance method (Thornthwaite \& Mather, 1957; Alley, 1984; Dingman, 2002; Legates \& Mccabe, 2005; Mccabe \& Markstrom, 2007; Westenbroek et al., 2010). Trends of main water balance components have been extensively analyzed globally. Gocic and Trajkovic (2014) analyzed data from 12 weather stations in a humid area of Serbia, for the period 1980 - 2010. They found significant increasing trends in $E T_{0}$ for the majority of the stations. Tabari et al. (2011) analyzed the annual, seasonal and monthly trends of the $E T_{0}$ series for 20 stations in the western half of Iran during 1966 - 2005. They concluded that the 
increasing trends in all seasons. This condition is followed by increasing trends in soil moisture deficit and drought occurrence. The similar results are found in Spain (Espadafor et al., 2011), Iran (Amirataee et al., 2016), Montenegro (Knežević et al., 2018), Slovenia (Zupanc \& Pintar, 2004) Brazil (Silva et al., 2016) and Togo (Djaman \& Komla, 2015). Likewise, many authors reported the increased trend in the annual value of potential evapotranspiration (Čadro et al., 2016), soil water deficit (Bukantis A. \& Rimkus E., 2005; Žurovec \& Čadro, 2010, 2015; Cammalleri et al., 2016) and drought severity (Vlahinić et al., 2001; Stankūnavičius, 2009; Žurovec et al., 2011; Hodžić et al., 2013; Taparauskienè \& Lukševičiūte, 2015; Čadro Sabrija et al., 2017; Merl, 2017) in humid areas of Bosnia and Herzegovina and Lithuania.

The main objective of this study is to determine and compare the severity of changes in mean annual water balance for two humid climatic zones (Lithuania and $\mathrm{B} \& \mathrm{H}$ ) using the linear regression methods, in order to understand how different areas of similar climate characteristics react to climate change and to analyze the severity of their influence.

\section{MATERIAL AND METHODS}

Two countries have been the subject of this research, Lithuania and Bosnia and Herzegovina (B\&H) (Figure 1). Lithuania is located in the Baltic region of northern-eastern Europe. The capital city is Vilnius, situated at latitude $54^{0} 41^{\prime} \mathrm{N}$ and longitude $25^{0} 19^{\prime}$ E. Bosnia and Herzegovina is located in south-eastern Europe, with capital city Sarajevo situated at latitude $43^{0} 52^{\prime} \mathrm{N}$ and longitude $18^{0} 25^{\prime}$ E. The basic characteristics of both countries are given in the Table 1.

Table 1. Lithuania and B\&H country profiles

\begin{tabular}{|c|c|c|}
\hline Characteristic & Lithuania & Bosnia and Herzegovina \\
\hline Area $\left(\mathrm{km}^{2}\right)$ & 65,300 & 51,129 \\
\hline Water (\%) & 1.35 & 1.4 \\
\hline Coastline $(\mathrm{km})$ & 90 & 20 \\
\hline Mean elevation (m) & 110 & 500 \\
\hline Highest point (m) & 297 & 2,386 \\
\hline GDP per capita ${ }^{1}$ & 18,857 & 5,806 \\
\hline Population & $2,823,859^{2}$ & $3,531,159^{3}$ \\
\hline Population density (per $\mathrm{km}^{2}$ ) & 43.24 & 69.06 \\
\hline $\mathrm{HDI}^{4}$ for 2017 & 0.858 & 0.768 \\
\hline $\mathrm{BTI}^{5}$ for 2017 & 9.24 & 6.28 \\
\hline Köppen climate classification ${ }^{6}$ & $D f b$ & $E T, D f b, C f a, C f b, C s a$ \\
\hline $\mathrm{CRI}^{7}$ for $1997-2016$ & 121.83 & 72.00 \\
\hline CRI rank & 136 & 69 \\
\hline \multicolumn{3}{|c|}{$\begin{array}{l}{ }^{1} \text { Gross domestic product, International Monetary Fund (2017). } \\
{ }^{2} \text { Estimation for 2017, Oficialiosios statistikos portalas. } \\
{ }^{3} \text { Agenncy for Statistics of Bosnia and Herzegovina, Census } 2013 \text { (Jukić, 2016). } \\
{ }^{4} \text { Human development index, source: United Nations Development Programme. } \\
{ }^{5} \text { Bertelsmann Stiftung's Transformation Index (Stiftung, 2018a, 2018b). } \\
\text { 'Dfb - humid continental climate, Cfa, Cfb - temperate warm and humid climates, Csa - mediterranean climate } \\
\text { and ET - tundra climate. }\end{array}$} \\
\hline
\end{tabular}




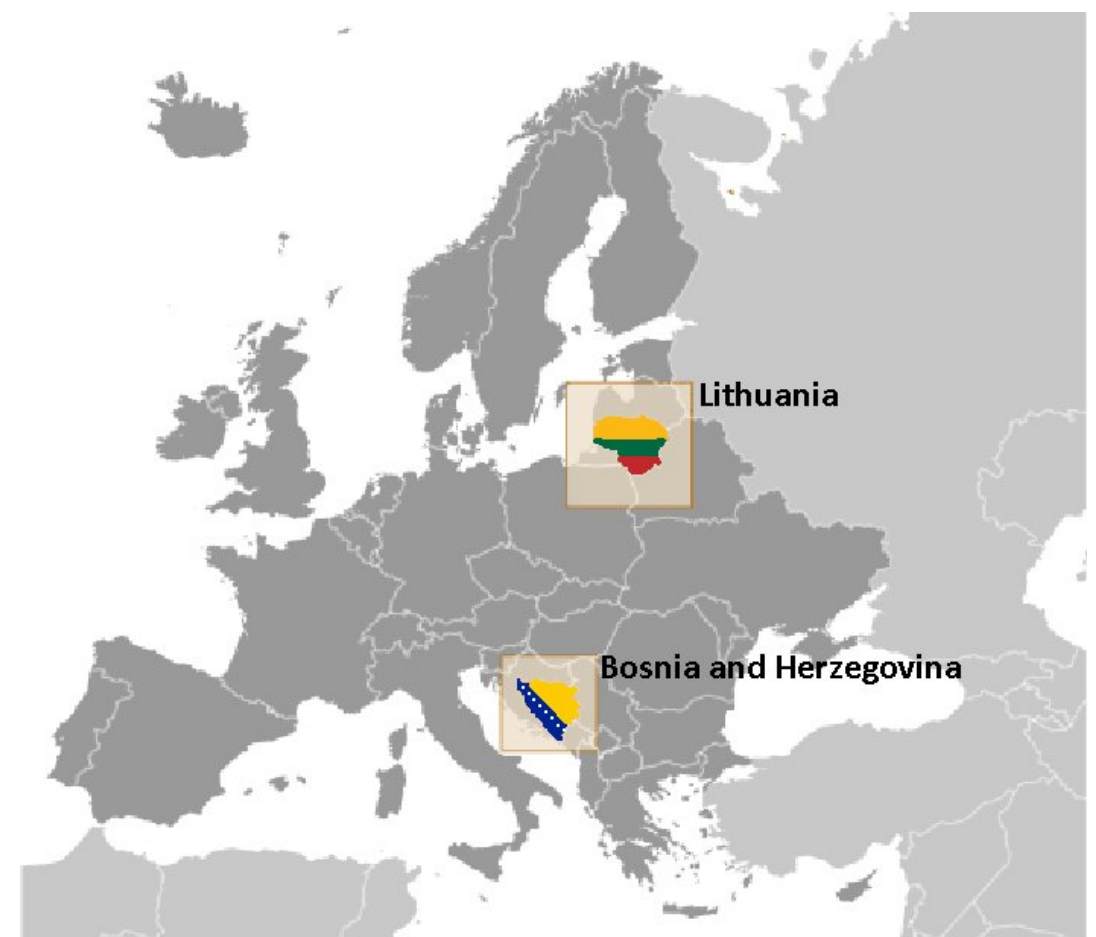

Figure 1: Locations of the Bosnia and Herzegovina and Lithuania with in the Europe

Humid climate prevails in both countries. In Lithuania, it is mostly humid continental climate $(D f b)$, while in B\&H in addition to $D f b$, temperate warm and humid climates $(C f a, C f b)$ and mediterranean climate (Giugliano et al.) are also present.

The Global Climate Risk Index 2018 (CRI) analyses to what extent countries have been affected by the impacts of weather-related loss events (storms, floods, heat waves etc.). Less developed countries are generally more affected than industrialized countries (Eckstein et al., 2018). The most recent data available from 1997 to 2016, places B\&H at $69^{\text {th }}$ place, and Lithuania at $136^{\text {th }}$.

Monthly climatic data, including mean maximum and minimum air temperature $\left({ }^{0} \mathrm{C}\right)$, minimum and maximum relative humidity (\%), wind speed (m $\mathrm{s}^{-1}$ ) and sunshine hours (h) from 2 humid weather stations (WS), Kaunas in Lithuania and Sarajevo in B\&H, for the period 1988 - 2017 (30 years) were obtained from state weather services. Before use, the data quality was checked with quality-control procedures recommended by Allen et al. (1998).

Reference evapotranspiration $\left(E T_{0}\right)$ was calculated using standard FAO$\mathrm{PM}$ equation (Eq. 1) that is closely resembling the evapotranspiration of an extension surface of green grass of uniform height $(0.12 \mathrm{~m})$, actively growing 
with enough water, with a fixed surface resistance $\left(70 \mathrm{~s} \mathrm{~m}^{-1}\right)$ and an albedo of 0.23, given by (Allen et al., 1998):

$$
E T_{0}=\frac{0.408 \Delta\left(R_{n}-G\right)+\gamma \frac{900}{T_{\text {mean }}+273} u_{2}\left(e_{s}-e_{a}\right)}{\Delta+\gamma\left(1+0.34 u_{2}\right)}
$$

where ETo is the reference evapotranspiration $\left(\mathrm{mm} \mathrm{day}^{-1}\right), R_{n}$ the net radiation at the crop surface $\left(\mathrm{MJ} \mathrm{m}^{-2}\right.$ day $\left.^{-1}\right), G$ the soil heat flux density ( $\mathrm{MJ} \mathrm{m}^{-2}$ day $\left.^{-1}\right), T_{\text {mean }}$ the mean daily air temperature at $2 \mathrm{~m}$ height $\left({ }^{\circ} \mathrm{C}\right), u_{2}$ the wind speed at $2 \mathrm{~m}$ height $\left(\mathrm{m} \mathrm{s}^{-1}\right), e_{s}$ the saturation vapor pressure, $e_{a}$ the actual vapor pressure, $e_{s}-e_{a}$ the saturation vapor pressure deficit, $\Delta$ the slope of the vapor pressure curve $\left(\mathrm{kPa}^{0} \mathrm{C}^{-1}\right)$ and $y$ is the psychrometric constant $\left(\mathrm{kPa}^{\circ} \mathrm{C}^{-1}\right)$.

All necessary parameters required for calculation of $E T_{0}$ where computed following the procedure developed in FAO-56 (Allen et al., 1998).

Since reflected solar radiation $\left(R_{S}\right)$ is required for $R_{n}$ calculation and this parameter is not measured on WS in B\&H, it was estimated from the measured sunshine hours data (The Campbell-Stokes sunshine recorder) with the Ångström (1924) equation:

$$
R_{s}=\left(a_{s}+b_{s} \frac{n}{N}\right) R_{a}
$$

where $R_{a}$ is the extraterrestrial radiation $\left(\mathrm{MJ} \mathrm{m}^{-2}\right.$ day $\left.^{-1}\right)$ calculated for each day of the year and for different latitudes, from the solar constant $\left(G_{s c}=0.0820\right.$ $\mathrm{MJ} \mathrm{m}^{-2} \mathrm{~min}^{-1}$ ), the solar declination $(\delta)$ and the time of the year $(J)$ and then by selecting the $R_{a}$ for 15th day of each month converted to monthly values, $n$ is the actual duration of sunshine (h), $N$ is the maximum possible duration of sunshine or daylight hours (h), as is the regression constant, expressing the fraction of extraterrestrial radiation reaching the earth on overcast days $(\mathrm{n}=0)$ and $a_{s}+b_{s}$ is the fraction of extraterrestrial radiation reaching the earth on clear days $(n=N)$.

In the absence of actual solar radiation $\left(R_{s}\right)$ measurements, the values $a_{s}=$ 0.25 and $b_{s}=0.5$ were used as suggested by Allen et al. (1998).

For the Kaunas WS measured solar radiation data $\left(R_{s}\right)$ or sunshine hours data were missing, so solar radiation was estimated using Hargreaves' formula (Hargreaves \& Samani, 1985) (Eq. 3), as suggested in Allen et al. (1998):

$$
R_{s}=k_{R_{s}} \sqrt{\left(T_{\max }-T_{\min }\right) \times R_{a}}
$$

where $R_{a}$ is extra-terrestrial radiation (MJ m-2 d-1), $T_{\max }$ maximum air temperature ( $\left.{ }^{\circ} \mathrm{C}\right), T_{\min }$ minimum air temperature $\left({ }^{\circ} \mathrm{C}\right), k_{R s}$ adjustment coefficient $\left(0.16\right.$.. 0.19) $\left({ }^{\circ} \mathrm{C}^{-0.5}\right)$.

In the case of Kaunas, since it is located inland ("interior" location) where land mass dominates and air masses are not strongly influenced by a large water body, value of $k_{R s}=0.16$ was used (Čadro S. et al., 2017). 
Monthly water balance was calculated as described in Dingman (2002). Except data on monthly precipitation $(P)$ and evapotranspiration $\left(E T_{0}\right)$ applied water balance requires data on soil available water content $\left(S O I L_{\max }\right)$. The value $S O I L_{\max }=100 \mathrm{~mm}$ was used (Mcbean et al., 1995) since this is the most commonly used value for the types of soil that are found on the study locations.

To detect the trends within time series of water balance components (annual precipitation, reference evapotranspiration, actual evapotranspiration, soil moisture deficit, total runoff and snow) parametric method of linear regression was used, as shown in equation (4):

$$
y=a+b \times x
$$

where $x$ is the explanatory variable, $y$ the dependent variable, $b$ the slope of the line and $a$ the intercept.

The slope indicates the mean temporal change of the studied variable. Positive values of the slope show increasing trends, while negative values of the slope indicate decreasing trends (Gocic \& Trajkovic, 2013, 2014).

\section{RESULTS AND DISCUSSION}

Descriptive statistics (mean, standard deviation - SD, coefficient of variation - CV) for the air temperature $(T)$, precipitation $(P), E T_{0}$ and via water balance calculated actual evapotranspiration (AET), soil moisture deficit (SMD), total runoff (TRO) and snow for the 2 WS for the period 1988 - 2017 are summarized in Table 2.

Table 2: Annual statistic for the climate and water balance components in Kaunas and Sarajevo WS during the period 1988-2017.

\begin{tabular}{lrrrrrrrr}
\hline Climate and water & \multicolumn{3}{c}{ Kaunas, Lithuania } & & \multicolumn{3}{c}{ Sarajevo, B\&H } \\
\cline { 2 - 4 } \cline { 7 - 8 } balance components & Mean & \multicolumn{1}{c}{ SD } & \multicolumn{1}{c}{ CV } & & Mean & \multicolumn{1}{c}{ SD } & \multicolumn{1}{c}{ CV } \\
\hline Air temperature $(T)$ & 7.27 & 0.81 & 11.19 & & 10.41 & 0.69 & 6.61 \\
Precipitation $(P)$ & 645 & 85.50 & 13.25 & & 947 & 156.51 & 16.52 \\
Reference $E T\left(E T_{0}\right)$ & 636 & 25.40 & 3.99 & & 805 & 45.17 & 5.61 \\
Actual $E T(A E T)$ & 503 & 56.63 & 11.25 & & 653 & 54.32 & 8.31 \\
Total runoff $(T R O)$ & 141 & 44.50 & 31.49 & & 295 & 86.78 & 29.47 \\
Soil m. deficit $(S M D)$ & 133 & 62.06 & 46.63 & & 151 & 85.69 & 56.70 \\
SNOW & 179 & 39.55 & 22.10 & & 193 & 99.11 & 51.33 \\
\hline
\end{tabular}

The averages of all analyzed and calculated climate and water balance characteristics are higher in Sarajevo than in Kaunas. The mean annual air temperature is $7.27{ }^{\circ} \mathrm{C}$ and $10.41{ }^{\circ} \mathrm{C}$ for Kaunas and Sarajevo, respectively. Annual sum of precipitation is for $302 \mathrm{~mm}$ higher in Sarajevo. These climatic differences have also caused the differences between water balance components. Mean $E T_{o}$ for Kaunas is slightly lower than the annual sum of precipitation, while in Sarajevo this difference is much higher $(142 \mathrm{~mm})$. In Sarajevo, a big part of precipitation cannot be lost to the atmosphere by evapotranspiration and it 
is retained by the soil or it appears in form of surface or subsurface runoff. Thus, total runoff (TRO) is much higher in Sarajevo than in Kaunas, $295 \mathrm{~mm}$ compared to $141 \mathrm{~mm}$. SMD and amount of snow have similar values between analyzed locations. The highest coefficient of variation (CV) is for SMD ranging from $46.63 \%$ in Kaunas to 56.70 \% in Sarajevo. These high SMD variations are in line with many previous studies of water scarcity and high sensitivity of this locations to climatic extremes (Čustović \& Vlahinić, 2004; Žurovec et al., 2011; Hodžić et al., 2013; Taparauskiene \& Lukševičiute, 2015; Taparauskienė et al., 2015; Radusin et al., 2016; Čadro Sabrija et al., 2017). Especially, this applies to agriculture production that depends on the soil moisture (Žurovec \& Čadro, 2015; Miseckaite et al., 2018). High variations were also obtained for total runoff (TRO) and snow ranging from 29.47 to $31.49 \%$ and 22.10 to $51.33 \%$ for Kaunas and Sarajevo, respectively.

Results of the regression analysis for annual air temperature (T), precipitation $(P), E T_{0}$ and via water balance calculated actual evapotranspiration $(A E T)$, soil moisture deficit (SMD), total runoff (TRO) and snow for the Kaunas and Sarajevo WS for the period 1988 - 2017 are presented in Table 3 and Fig. 2.

Table 3. Results for the statistical tests for the annual climate and water balance components in Kaunas and Sarajevo WS during the period 1988-2017.

\begin{tabular}{|c|c|c|c|c|c|c|c|c|}
\hline \multirow{2}{*}{$\begin{array}{l}\text { Climate and } \\
\text { water } \\
\text { balance } \\
\text { components }\end{array}$} & \multicolumn{4}{|c|}{ Kaunas, Lithuania } & \multicolumn{4}{|c|}{ Sarajevo, B\&H } \\
\hline & $\begin{array}{c}\text { p- } \\
\text { value }\end{array}$ & $\mathbf{R}$ & $\mathbf{R}^{2}$ & b & $\begin{array}{c}\text { p- } \\
\text { value }\end{array}$ & $\mathbf{R}$ & $\mathbf{R}^{2}$ & b \\
\hline$T$ & 0.001 & 0.562 & 0.316 & 0.052 & 0.000 & 0.607 & 0.368 & 0.047 \\
\hline$P$ & 0.044 & 0.369 & 0.136 & 3.582 & 0.610 & 0.097 & 0.009 & 1.724 \\
\hline$E T_{0}$ & 0.003 & 0.521 & 0.271 & 1.503 & 0.130 & 0.282 & 0.079 & 1.450 \\
\hline$A E T$ & 0.003 & 0.521 & 0.272 & 3.355 & 0.409 & 0.156 & 0.024 & 0.965 \\
\hline TRO & 0.617 & 0.094 & 0.009 & -0.480 & 0.793 & 0.049 & 0.002 & 0.492 \\
\hline$S M D$ & 0.161 & 0.262 & 0.069 & -1.851 & 0.794 & 0.050 & 0.002 & 0.485 \\
\hline SNOW & 0.008 & 0.471 & 0.222 & -2.114 & 0.759 & 0.058 & 0.003 & -0.656 \\
\hline
\end{tabular}

The results clearly show increasing trends in $T, P, E T_{0}$ and $A E T$ series and decreasing trend in the amount of the snow. The increasing trends of the air temperature $(T)$ are similar for Kaunas and Sarajevo WS, ranging from $0.052{ }^{\circ} \mathrm{C}$ to $0.047{ }^{0} \mathrm{C}$. Increasing trends ware also detected for the annual amount of precipitation, ranging from $3.582 \mathrm{~mm}_{\text {year }}{ }^{-1}$ in Kaunas to $1.724 \mathrm{~mm}_{\text {year }}{ }^{-1}$ in Sarajevo, Annual sum of precipitation has increased by more than $100 \mathrm{~mm}$ in Kaunas for a period of 30 years (1988-2017). The observed air temperature and precipitation change patterns in Lithuania and $\mathrm{B} \& \mathrm{H}$ are consistent with the predominant trends in other areas of East Europe (Bukantis A. \& Rimkus E., 2005; Bukantis ArūNas \& Rimkus Egidijus, 2005; Jaagus et al., 2009; Branković et al., 2013; Burić et al., 2013; Tripolskaja \& Pirogovskaja, 2013; Unkasevic \& 
Tosic, 2013; Rutgersson et al., 2014) and with trends observed globally (Kharin et al., 2013; Trenberth et al., 2013; Jacob et al., 2018; Popov et al., 2018).

The annual increasing $E T_{0}$ trends between Kaunas and Sarajevo are similar, they ranged from $1.503 \mathrm{~mm}_{\text {year }}{ }^{-1}$ to $1.450 \mathrm{~mm}_{\text {year }}{ }^{-1}$. However, the annual increasing trend of $A E T$ has a lot higher rate in Kaunas than Sarajevo. The magnitude of increasing trends of annual AET varied from $3.355 \mathrm{~mm} \mathrm{year}^{-1}$ in Kaunas to $0.965 \mathrm{~mm}$ year $^{-1}$ in Sarajevo. Since AET can be considered as the measure of agricultural water productivity, obtained results indicate an improvement of general conditions for agricultural production. This is especially true for the study location in Lithuania (Kaunas). This indicates that the consequences of climate change are predominantly, but not exclusively negative and dependent on geographical location. Climate change may have a positive effect on the yield and quality of winter crops due to the extended growing period in northern Europe (Radusin et al., 2016; Jacob et al., 2018). However, the rest of Europe, especially the Mediterranean region, will mostly be negatively affected (Behrens et al., 2010).

A negative trend in TRO was found for Kaunas, which decreased by 0.480 $\mathrm{mm}$ each year, and positive in Sarajevo, with an increase of $0.492 \mathrm{~mm}$ each year. Furthermore, there is a decreasing trend in the amount of snow in both locations, from $-2.114 \mathrm{~mm}_{\text {year }}{ }^{-1}$ to $0.656 \mathrm{~mm}_{\text {year }}{ }^{-1}$. Such runoff and snow amount trends have already been recorded in Lithuania (Stonevičius et al., 2014) and they are results of changes in influencing climatic elements - temperature and precipitation (Bukantis ArūNas \& Rimkus Egidijus, 2005).

Soil moisture deficit occurs when the demand for water $\left(E T_{0}\right)$ exceeds that which is actually available from the precipitation $(P)$ or reserved in the soil (Žurovec \& Čadro, 2015). In terms of SMD, two analyzed locations differ. The increasing trend in the SMD was found for Sarajevo $\left(0.485 \mathrm{~mm} \mathrm{year}^{-1}\right)$ and decreasing for Kaunas $\left(-2.114 \mathrm{~mm}\right.$ year $\left.^{-1}\right)$. Presence of positive trend in SMD causing more severe long-lasting droughts and yield reduction was found all over B\&H (Vlahinić, 2000; Alagić, 2003; Žurovec \& Čadro, 2010; Čadro Sabrija et al., 2017).

Linear trends, correlation coefficient $(R)$ and coefficient of determination $\left(R^{2}\right)$ of annual air temperature $(T)$, precipitation $(P)$, reference evapotranspiration $\left(E T_{0}\right)$, actual evapotranspiration (AET), soil moisture deficit $(S M D)$ and total runoff (TRO) for the both analyzed locations are presented in Table 3. and Figure 2 . The values of $R$ and $R^{2}$ for all analyzed parameters are generally lower for Sarajevo than Kaunas. This is the result of much higher variations in the annual values of all the obtained parameters in Sarajevo. Variations can be clearly seen in Figure 2, or by comparing the standard deviation (SD) and coefficient of variation (CV) between these two locations (Table 2). The annual amount of precipitation, TRO, SMD and snow showed the highest variations. Such variations indicate extreme weather conditions, shifting between years with extremely high levels of precipitation, causing soil erosion, landslides and floods, and years with low precipitation causing prolonged droughts and serious yield declines. Agriculture is one of the most important socioeconomic sectors in $\mathrm{B} \& \mathrm{H}$, but at same time a sector mostly affected by climate change (Žurovec et al., 2015). 


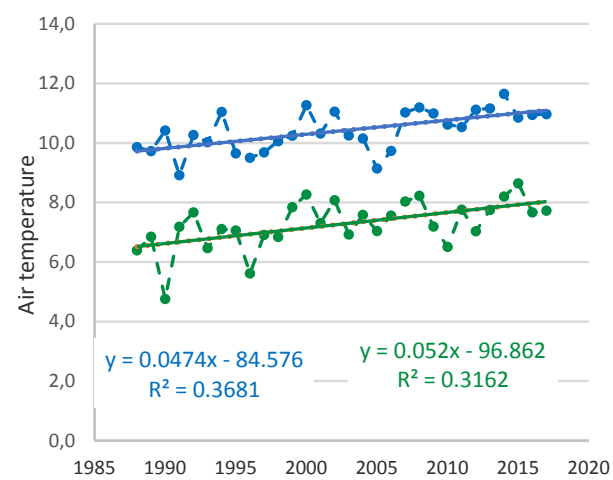

(a)

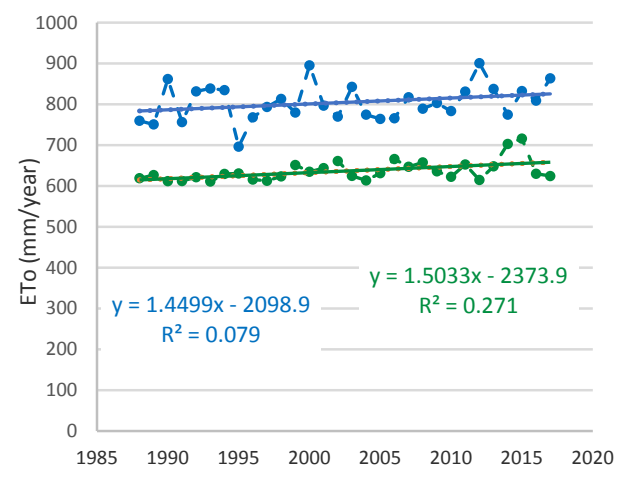

(c)

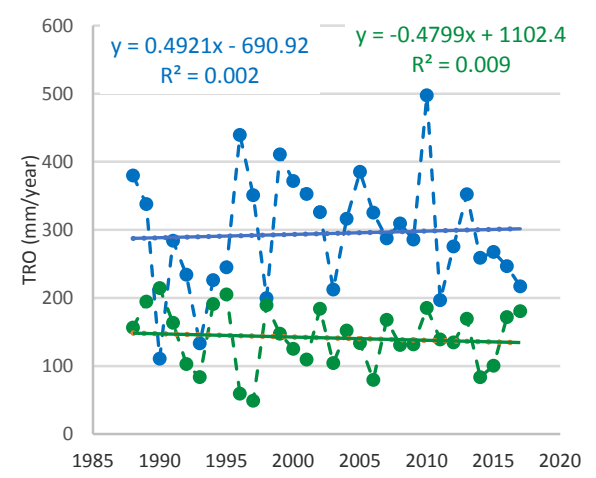

(e)

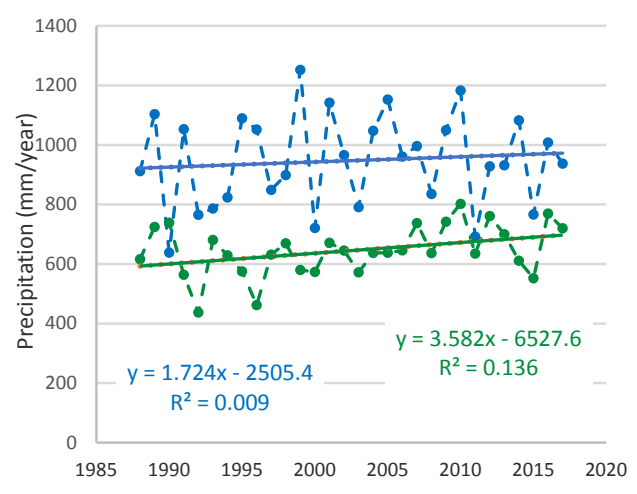

(b)

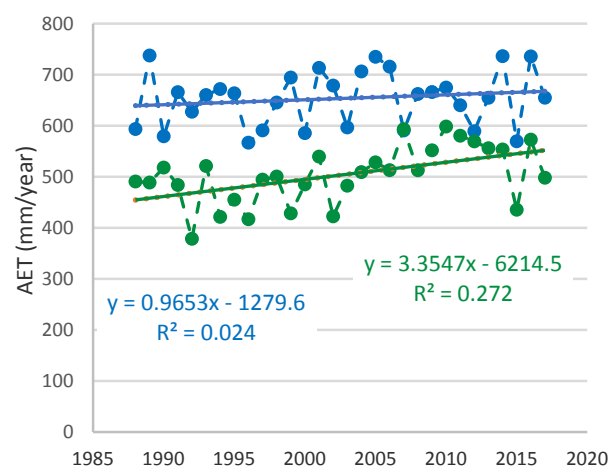

(d)

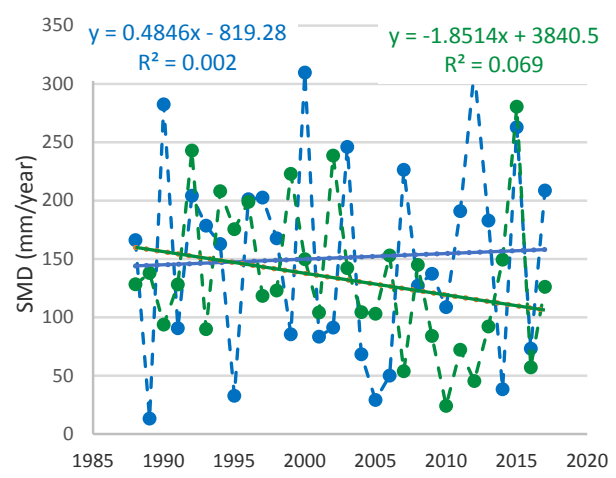

(f)

\section{- - - - Sarajevo}

\section{$--\bullet-$ Kaunas}

Figure 2: Linear trends, correlation coefficient $(R)$ and coefficient of determination $\left(R^{2}\right)$ of annual air temperature (a), precipitation (b), reference evapotranspiration (c), actual evapotranspiration (d), soil moisture deficit (e), and total runoff (f) are presented for the Kaunas and Sarajevo weather stations for the period 1988 - 2017. 
There is an obvious need for planning and implementation of appropriate measures of adaptation to climate change (Zurovec et al., 2017; Assan et al., 2018). In the first place developing of the appropriate irrigation systems should be a preferred option, as well as the development and introduction of varieties resistant to dry climate conditions. Irrigation will certainly be one of the key mechanisms for adaptation. However, flood protection and drainage of excess waters from the plot, and in general regulation of water and air regime is a matter of priority for further development of the agricultural sector (Radusin et al., 2016).

\section{CONCLUSIONS}

Linear regression was applied to analyze annual trends in the air temperature, precipitation, FAO-56 PM reference evapotranspiration and water balance components (actual evapotranspiration, total runoff, soil moisture deficit and amount of snow). Monthly weather data from two humid weather stations, Kaunas (Lithuania) and Sarajevo (Bosnia and Herzegovina), for the time period of 30 years $(1988$ - 2017) were used. The main purpose was to determine and compare the severity of changes in mean annual water balance components for two humid climatic zones.

Results indicated that climate change differently affects the water balance of these two humid areas. Increasing trends in $T, P, E T_{0}$ and $A E T$ series and decreasing trend in the amount of the snow were found. Both locations are showing a positive trend of reference evapotranspiration, with an increase of $1.450 \mathrm{~mm}$ year ${ }^{-1}$ to $1.503 \mathrm{~mm}$ year $^{-1}$. Increasing trends of annual AET varied from $3.355 \mathrm{~mm}$ year $^{-1}$ in Kaunas to $0.965 \mathrm{~mm}$ year $^{-1}$ in Sarajevo. However, total runoff and soil moisture deficit are decreasing in Kaunas $(-0.480 \mathrm{~mm}$ and $-2.114 \mathrm{~mm}$ year $^{-1}$, respectively) and increasing in Sarajevo $\left(0.492 \mathrm{~mm}\right.$ and $0.485 \mathrm{~mm}_{\text {year }}{ }^{-1}$, respectively). In general, results showed an increase in irrigation water demand for agricultural crops in Sarajevo (Bosnia and Herzegovina) and decrease in Kaunas (Lithuania).

Compared to Lithuania, location in B\&H is highly vulnerable to climate change. High sensitivity is the result of large variations and positive trends of almost all analyzed parameters. The annual amount of precipitation, total runoff, soil moisture deficit and snow showed the highest variations (16.54 - 56.70 \%). In comparison, same parameters for the area of Lithuania (Kaunas), indicate that climate change may have some positive effects on general conditions for agricultural production, such as increase of precipitation and actual evapotranspiration, and the decline in soil moisture deficit.

\section{REFERENCES}

Alagić, E. (2003). Navodnjavanje-Preventivna Zaštita od Suše u Bosni i Hercegovini. Paper presented at the Vodoprivreda 0350-0519, Bosna i Hercegovina.

Allen, R. G., Pereira, L., Raes, D., \& Smith, M. (1998). Crop evapotranspiration: Guidelines for computing crop water requirements. New York: United Nations FAO. 
Alley, W. M. (1984). On the Treatment of Evapotranspiration, Soil Moisture Accounting, and Aquifer Recharge in Monthly Water Balance Models. Water Resources Research, 20(8), 1137-1149.

Amirataee, B., Montaseri, M., \& Sanikhani, H. (2016). The analysis of trend variations of reference evapotranspiration via eliminating the significance effect of all autocorrelation coefficients. Theoretical and Applied Climatology, 126(1-2), 131-139. doi: 10.1007/s00704-015-1566-z

Ångström. (1924). Solar and terrestrial radiation. Quaterly Journal of Royal Meteorological Society, 50, 121-125.

Assan, E., Suvedi, M., Schmitt Olabisi, L., \& Allen, A. (2018). Coping with and Adapting to Climate Change: A Gender Perspective from Smallholder Farming in Ghana. Environments, 5(8), 86. doi: 10.3390/environments5080086

Behrens, A., Georgiev, A., \& Carraro, M. (2010). Future Impacts of Climate Change across Europe CEPS Working Document No. 324/February 2010 Centre for European Policy Studies.

Branković, Č., Cindrić, K., Gajić-Čapka, M., Güttler, I., Pandžić, K., Patarčić, M., . . . Zaninović, K. (2013). Sixth National Communication of the Republic of Croatia under the United Nation Framework Convention on the Climate Change (UNFCCC) Selected Sections in Chapters: 7. Climate Change Impacts and Adaptation Measures 8. Resarch, Systematic Observation and Monitoring. . Zagreb, Croatia: Meteorological and hydrological service of Croatia.

Bukantis, A., \& Rimkus, E. (2005). Climate variability and change in Lithuania. Acta Zoologica Lituanica, 15(2), 100-104.

Bukantis, A. n., \& Rimkus, E. (2005). Climate Variability and Change in Lithuania. Acta Zoologica Lituanica, 15(2).

Burić, D., Ducić, V., Mihajlović, J., Luković, J., \& Dragojlović, J. (2013). Recent Extreme Air Temperature Changes in Montenegro. Bulletin of the Serbian Geographical Society, XCV(4), 53-66.

Cammalleri, C., Micale, F., \& Vogt, J. (2016). Recent temporal trend in modelled soil water deficit over Europe driven by meteorological observations. International Journal of Climatology, 36(15), 4903-4912. doi: 10.1002/joc.4677

Čadro, S., Uzunović, M., Žurovec, J., \& Žurovec, O. (2017). Validation and calibration of various reference evapotranspiration alternative methods under the climate conditions of Bosnia and Herzegovina. International Soil and Water Conservation Research, 5(4), 309-324. doi: 10.1016/j.iswcr.2017.07.002

Čadro, S., Žurivec, J., Mrkulić, A., Šehić, D., Šero, A., \& Mićić, G. (2016). Effect of Climate Change on Agro Hydrological Balance for Some Regions in Bosnia and Herzegovina. Paper presented at the VII International Scientific Agricultural Symposium "Agrosym 2016", Jahorina.

Čadro, S., Žurovec, J., \& Cherni-Čadro, S. (2017). Severity, Magnitude and Duration of Droughts in Bosnia and Herzegovina Using Standardized Precipitation Evapotranspiration Index (SPEI). Agriculture \& Forestry, 63(3), 199-206. doi: DOI:10.17707/AgricultForest.63.3.20.

Čustović, H., \& Vlahinić, M. (2004). Vodni bilans zemljišta Bosne i Hercegovine u cilju prevencije erozije, suše i poplava. Sarajevo: Univerzitet u Sarajevu, Poljoprivredno-prehrambeni fakultet.

Dingman, S. L. (2002). Physical hydrology (2nd ed.). 
Djaman, K., \& Komla, G. (2015). Trend analysis in reference evapotranspiration and aridity index in the context of climate change in Togo. Journal of Water and Climate Change, 6(4), 848-864. doi: 10.2166/wcc.2015.111

Easterling, D. R., Evans, J., Groisman, P. Y., Karl, T., Kunkel, K. E., \& Ambenje, P. (2000). Observed variability and trends in extreme climate events: a brief review. Bull. Am. Meteorol. Soc., 81(417-425).

Eckstein, D., Künzel, V., \& Schäfer, L. (2018). Global Climate Risk Index 2018 (pp. 36 p.). Bonn, Germany.

Espadafor, M., Lorite, I. J., Gavilan, P., \& Berengena, J. (2011). An analysis of the tendency of reference evapotranspiration estimates and other climate variables during the last 45 years in Southern Spain. Agricultural Water Management, 98(6), 1045-1061. doi: 10.1016/j.agwat.2011.01.015

Giugliano, R. P., Ruff, C. T., Braunwald, E., Murphy, S. A., Wiviott, S. D., Halperin, J. L., . . . Duprat, C. (2013). Edoxaban versus Warfarin in Patients with Atrial Fibrillation. New England Journal of Medicine, 369(22), 2093-2104. doi: 10.1056/Nejmoa1310907

Gocic, M., \& Trajkovic, S. (2013). Analysis of changes in meteorological variables using Mann-Kendall and Sen's slope estimator statistical tests in Serbia. Global and Planetary Change, 100, 172-182. doi: 10.1016/j.gloplacha.2012.10.014

Gocic, M., \& Trajkovic, S. (2014). Analysis of trends in reference evapotranspiration data in a humid climate. Hydrological Sciences Journal-Journal Des Sciences Hydrologiques, 59(1), 165-180. doi: 10.1080/02626667.2013.798659

Hargreaves, G. H., \& Samani, Z. A. (1985). Reference crop evapotranspiration from temperature. Transaction of ASAE, 1(2), 96-99.

Hodžić, S., Marković, M., \& Čustović, H. (2013). Drought Conditions and Management. Strategies in Bosnia and Herzegovina - Concise Country Report UNW-DPC Proceedings (Vol. 11).

Jaagus, J., Briede, A., Rimkus, E., \& Remm, K. (2009). Precipitation pattern in the Baltic countries under the influence of large-scale atmospheric circulation and local landscape factors. International Journal of Climatology, 30(5), 705 - 720. doi: 10.1002/joc. 1929

Jacob, D., Kotova, L., Teichmann, C., Sobolowski, S. P., Vautard, R., Donnelly, C., . . . van Vliet, M. T. H. (2018). Climate Impacts in Europe Under $+1.5^{\circ} \mathrm{C}$ Global Warming. Earth's Future, 6(2), 264-285. doi: 10.1002/2017ef000710

Jukić, V. (2016). Cenzus of Population, Households and Dwellings in Bosnia And Herzegovina, 2013 Final Results. In A. z. p. i. p. "Libar" (Ed.), (pp. 258). Sarajevo, Bosna i Hercegovina: Agency for Statistics of Bosnia and Herzegovina.

Kharin, V. V., Zwiers, F. W., Zhang, X., \& Wehner, M. (2013). Changes in temperature and precipitation extremes in the CMIP5 ensemble. Climatic Change, 119(2), 345-357. doi: 10.1007/s10584-013-0705-8

Knežević, M., Zivotić, L., Čereković, N., Topalović, A., Koković, N., \& Todorovic, M. (2018). Impact of climate change on water requirements and growth of potato in different climatic zones of Montenegro. Journal of Water and Climate Change, jwc2018211. doi: 10.2166/wcc.2018.211

Legates, D. R., \& McCabe, G. J. (2005). A re-evaluation of the average annual global water balance. Physical Geography, 26, 12.

McBean, E. A., Rovers, F. A., \& Farquhar, G. J. (1995). Soil Waste Landfill Engineering and Design. New Jersey: Prentice Hall PRT: Englewood Cliffs. 
McCabe, G. J., \& Markstrom, S. L. (2007). A monthly water-balance model driven by a graphical user interface Open-File Report 2007-1088 (pp. 6). Reston, Virginia: U.S. Geological Survey.

MERL. (2017). Lithuania's 7th National Communication under the United Nations Framework Convention on Climate Change. Vilnius, Lithuania: Ministry of Environment of the Republic of Lithuania.

Miseckaite, O., Čadro, S., Tunguz, V., Lukashevich, V., Šimunić, I., \& Orlović-Leko, P. (2018). Climate and aridity change. Paper presented at the 8TH Asian Regional Conference (8ARC): Irrigation in Support of Evergreen Revolution, Kathmandu, Nepal.

Pandey, P. K., Dabral, P. P., \& Pandey, V. (2016). Evaluation of reference evapotranspiration methods for the northeastern region of India. International Soil and Water Conservation Research, 4(1), 52-63. doi: 10.1016/j.iswcr.2016.02.003

Pereira, L. S., Allen, R. G., Smith, M., \& Raes, D. (2015). Crop evapotranspiration estimation with FAO56: Past and future. Agricultural Water Management, 147, 4-20. doi: 10.1016/j.agwat.2014.07.031

Popov, T., Gnjato, S., Trbic, G., \& Ivanisevic, M. (2018). Recent Trends in Extreme Temperature Indices in Bosnia and Herzegovina. Carpathian Journal of Earth and Environmental Sciences, 13(1), 211-224. doi: 10.26471/cjees/2018/013/019

Popov, T., Gnjato, S., Trbić, G., \& Ivanišević, M. (2017). Trends in extreme daily precipitation indices in Bosnia and Herzegovina. Collection of Papers - Faculty of Geography at the University of Belgrade, 65(1). doi: doi:10.5937/zrgfub1765005P

Povilaitis, A., Rudzianskaite, A., Miseviciene, S., Gasiunas, V., Miseckaite, O., \& Zivatkauskiene, I. (2018). Efficiency of Drainage Practices for Improving Water Quality in Lithuania. Transactions of the Asabe, 61(1), 179-196. doi: 10.13031/trans.12271

Radusin, S., Medić, V., Cero, M., Abdurahmanović, I., Avdić, S., Oprašić, S., . . Trbić, G. (2016). Third National Communication and Second Biennial Update Report on Greenhouse Gas Emissions of Bosnia And Herzegovina under the United Nations Framework Convention on Climate Change. Sarajevo.

Radusin, S., Oprašić, S., Cero, M., Abdurahmanović, I., Vukmir, G., Avdić, S., . . . Jakšić, B. (2013). Second National Communication of Bosnia and Herzegovina under the United Nations Framework Convention on Climate Change.

Rutgersson, A., Jaagus, J., Schenk, F., \& Stendel, M. (2014). Observed changes and variability of atmospheric parameters in the Baltic Sea region during the last 200 years. Climate Research, 61(2), 177-190. doi: 10.3354/cr01244

Sharma, V., \& Irmak, S. (2012). Mapping Spatially Interpolated Precipitation, Reference Evapotranspiration, Actual Crop Evapotranspiration, and Net Irrigation Requirements in Nebraska: Part I. Precipitation and Reference Evapotranspiration. Transactions of the Asabe, 55(3), 907-921.

Silva, H. J. F. d., Lucio, P. S., \& Brown, I. F. (2016). Trend analysis of the reference evapotranspiration for the southwestern Amazon, Brazil. Journal of Hyperspectral Remote Sensing, 6(5), 270-282. doi: 10.5935/22372202.20160027

Simonovic, S. P., \& Li, L. (2004). Sensitivity of the Red River Basin flood protection system to climate variability and change. Water Resources Management, 18(2), 89-110. 
Stankūnavičius, G. (2009). Ilgalaikių oro temperatūros ir kritulių anomalijų numatymo galimybès Lietuvoje. Geografija, 45(1), 33-43.

Stiftung, B. (2018a). BTI 2018 Country Report - Bosnia and Herzegovina.

Stiftung, B. (2018b). BTI 2018 Country Report — Lithuania.

Stonevičius, E., Valiuškevičius, G., Rimkus, E., \& Kažys, J. (2014). Climate induced changes of Lithuanian rivers runoff in 1960-2009. Water Resources, 41(5), 592603. doi: 10.1134/s0097807814050133

Tabari, H., Marofi, S., Aeini, A., Talaee, P. H., \& Mohammadi, K. (2011). Trend analysis of reference evapotranspiration in the western half of Iran. Agricultural and Forest Meteorology, 151(2), 128-136. doi: 10.1016/j.agrformet.2010.09.009

Taparauskiene, L., \& Lukševičiute, V. (2015). Drought Occurrance under Lithuanian Climatic Conditions. Paper presented at the 7th International Scientific Conference Rural Development 2015, Lithuania.

Taparauskienè, L., \& Lukševičiūtė, V. (2015). Drought Occurrence Under Lithuanian Climatic Conditions. Paper presented at the 7th International Scientific Conference Rural Development, Aleksandras Stulginskis University, Lithuania.

Taparauskiene, L., Tanaskovik, V., Miseckaite, O., Inga, A., \& Burbulis, N. (2015). Recommendations for Agricultural Drought Assessment under Lithuanian Climatic Conditions. Paper presented at the 2nd International Symposium for Agriculture and Food, Ohrid, Makedonia.

Thornthwaite, C. W., \& Mather, J. R. (1955). The water balance. Publications in Climatology, Centerton.

Thornthwaite, C. W., \& Mather, J. R. (1957). Instructions and Tables for Computing Potential Evapotranspiration and the Water Balance. Climatology, X(3).

Trbic, G., Popov, T., \& Gnjato, S. (2017). Analysis of air temperature trends in Bosnia and Herzegovina. Geographica Pannonica, 21(2), 68-84. doi: 10.18421/Gp21.02-01

Trenberth, K. E., Dai, A., van der Schrier, G., Jones, P. D., Barichivich, J., Briffa, K. R., \& Sheffield, J. (2013). Global warming and changes in drought. Nature Climate Change, 4, 17. doi: 10.1038/nclimate2067

Tripolskaja, L., \& Pirogovskaja, G. (2013). Impact of climate variability in Lithuania and Belarus on atmospheric precipitation infiltration: lysimetric study. ZemdirbysteAgriculture, 100(4), 369-376. doi: 10.13080/z-a.2013.100.047

Unkasevic, M., \& Tosic, I. (2013). Trends in temperature indices over Serbia: relationships to large-scale circulation patterns. International Journal of Climatology, 33(15), 3152-3161. doi: 10.1002/joc.3652

Vlahinić, M. (2000). Hidroakumulacije, poljoprivreda i zemljišno-vodni menadžment u Bosni I Hercegovini. Voda i mi, 27, 12.

Vlahinić, M., Čustović, H., \& Alagić, E. (2001). Situation of Drought in Bosnia and Herzegovina.

Westenbroek, S. M., Kelson, V. A., Dripps, W. R., Hunt, R. J., \& Brandbury, K. R. (2010). SWB-A modified Thornthwaite-Mather Soil Water Balance code for estimating groundwater recharge. U.S. Geological Survey Techniques and Methods, 6(A31), 60.

Zupanc, V., \& Pintar, M. (2004). Estimating Climate Change Impact On Irrigation Demand Using Integrated Modelling. Paper presented at the BALWOIS, Ohrid, FY Republic of Macedonia. 
Zurovec, O., Cadro, S., \& Sitaula, B. K. (2017). Quantitative Assessment of Vulnerability to Climate Change in Rural Municipalities of Bosnia and Herzegovina. Sustainability, 9(7). doi: 10.3390/Su9071208

Žurovec, J. (2012). Melioracije $i$ uređenje poljoprivrednog zemljišta. Sarajevo: Univerzitet u Sarajevu, Poljoprivredno-prehrambeni fakultet.

Žurovec, J., \& Čadro, S. (2010). Klimatske promjene, potreba i značaj navodnjavanja poljoprivrednih kultura na području sjeveroistočne BiH. Paper presented at the 21st Scientific-Expert Conference in Agriculture and Food Industry, Neum, Bosnia and Herzegovina.

Žurovec, J., \& Čadro, S. (2015). Temporal Drought and Soil Moisture Variability in the Arable Land of Spreča Valley. Paper presented at the 26th International Scientific expert Conference in Agriculture and Food Industry, Ilidža, Sarajevo.

Žurovec, J., Čadro, S., \& Murtić, S. (2011). Drought Analysis in Sarajevo Using Standardized Precipitation Index (SPI). Paper presented at the 22nd International Scientific expert Conference in Agriculture and Food Industry, Sarajevo.

Žurovec, O., Čadro, S., \& Sitaula, B. K. (2017). Quantitative Assessment of Vulnerability to Climate Change in Rural Municipalities of Bosnia and Herzegovina. Sustainability, 9(1208), 18. doi: 10.3390/su9071208

Žurovec, O., Vedeld, P. O., \& Sitaula, B. K. (2015). Agricultural Sector of Bosnia and Herzegovina and Climate Change-Challenges and Opportunities. Agriculture, 5(2), 245-266. doi: 10.3390/agriculture5020245 